\title{
Supply Chain Analysis of Kataribhog (Aman Season) Rice at Dinajpur District in Bangladesh
}

\author{
Md. Imran Omar* Mohammad Chhiddikur Rahman \\ Afroza Chowdhury Md. Abu Bakr Siddique \\ Agricultural Economics Division, Bangladesh Rice Research Institute
}

\begin{abstract}
The purpose of this study was to investigate the Value Chain of Kataribhog (aromatic) rice at Dinajpur district in Bangladesh. A structured interview schedule was used for primary data collected from the rice farmers. The findings of this study revealed that the yield of Kataribhog rice was $1250 \mathrm{~kg}$ /acre and gross return was 51,200 Tk./acre. The cost of cultivation of Kataribhog rice was $38045.75 \mathrm{Tk}$./acre. On full and current cost basis the Benefit Cost Ratio (BCR) was found 1.35 and 2.05, respectively. About $75 \%$ of the produced aromatic rice was supplied to the domestic market by the millers and different companies. Remaining 25\% was exported in different countries. The study also found that, on an average the marketing cost of aromatic rice for bepari, aratdar (paddy), miller, aratdar (rice), wholesaler and retailer were estimated as Tk. 81.90, Tk. 91.80, Tk.761.71 Tk. 73.49, Tk. 95.57, and Tk. 75.57, per quintal respectively. The share of net margin (other than the farmers) earned by the faria/bepari, paddy aratdar, miller, aratdar (rice), wholesaler and retailer was estimated as $7.56 \%$, $9.42 \%, 42.75 \%, 11.02 \%, 11.33 \%$ and $17.92 \%$, respectively. The producer share to the total rice value was $63.53 \%$ with a farm-retail price spread of Tk. 2612 per quintal. In the study area, major constraints found for aromatic rice production were labor unavailability, pest and disease problem, high cost of input, high cost of labor, lodging problems. Besides, the constraints associated with aromatic rice marketing were lack of storage facilities, lack of price regulation and execution. Proper planning and measure from the government side to solve the problems in the production and marketing would encourage farmers for better production and distribution of aromatic rice in the country.
\end{abstract}

Keywords: Value addition, marketing margins, price spread and producers share

DOI: $10.7176 / \mathrm{EJBM} / 11-1-02$

\section{Introduction}

Rice is being cultivated in three distinct seasons in Bangladesh namely Aman, Aus and Boro (BBS 2016). Among three seasons, Aman rice has greater commercial importance in terms of trade volume and high value. Generally, this season is much useful for aromatic rice cultivation. Fine and aromatic rice have high commercial importance with greater economic return. Noteworthy, Bangladesh has about 54 aromatic and fine rice varieties that are being grown in different part of the country. The area coverage under aromatic rice is $12.5 \%$ in $\mathrm{Aman}$ season (Islam et al. 2018) and their yield based on clean rice was nearly 2.0 per hectare (Rashid et al. 2017). Among the aromatic rice varieties, Kataribhoge is a famous local variety which is mostly cultivated in Dinajpur district. Kataribhoge is famous for making delicious flatten rice. Flatten rice from Kataribhoge is light white color and sweet flavored. Boild Rice and Polau rice of Kataribhoge are very much popular throughout the country. The yield performance of Kataribhog is little higher than the average yield of aromatic rice in Bangladesh. Rashid et al. (2017) estimated the yield of Kataribhoge as $2.54 \mathrm{t} / \mathrm{ha}$. For its geographical and environmental advantages, Dinajpur district is highly concentrated for aromatic rice production. Various rice processing companies like ACI, Pran Group and Square Company Limited have established aromatic rice processing plant in Dinajpur. In 2017-18 about 15,540 hectares of land was under Kataribhog rice, which was about 5.6\% of total Aman area and from where 36,460 tons of clean rice was produced with an average yield of $2.37 \mathrm{t} / \mathrm{ha}$ in this district (DAE 2017). Bangladeshi aromatic rice is expected to have a good market demand in international context for its nice aroma and fine grain quality. With low production cost and natural facilities, Bangladesh could enjoy a good opportunity to export aromatic and fine grain rice to abroad because of higher demand in the world market. So far, a few studies have been conducted on the marketing system of fine grain paddy/rice in Bangladesh. However, there is no exclusive study on the marketing system of Kataribhog rice. As such it was felt that a study on the Kataribhog rice in the Dinajpur area would be of much importance. The present study is a modest attempt to describe the marketing of Kataribhog rice stating the problems of its production and marketing and giving some solutions. The study provided useful information to the producers, traders, consumers, researchers and planners for the production and distribution of Kataribhog rice. The study has been carried out based on the objectives of mapping the value chain network and value adding process along the supply chain. Estimating production and marketing costs and return, marketing margin and price spread. Besides, this study focused on the constraints and opportunities along the value chain of Kataribhog rice in Bangladesh. 


\section{Methodology}

In order to collect the primary data, two Upazilas of Dinajpur district were selected purposively on the basis of a higher concentration of Kataribhog rice production and distribution. These Upazilas are Dinajpur Sadar and Birampur. The study purposively selected a sample size of 100, includes 30 farmers, 20 paddy traders, 20 rice millers and 30 rice traders. The structured interview schedule was applied to collect information from farmers, millers and traders levels who produced, processed and traded aromatic and fine rice. The survey was conducted during the period November 2017 to April 2018. Both tabular and descriptive statistics techniques were employed to analyze the data.

\section{Analytical tools:}

\section{Cost and return analysis}

Following profit equation was employed to assess the profitability of paddy and head rice production.

Net return/Value addition of producer

$$
\Pi=\mathrm{P}_{\mathrm{F}} \cdot \mathrm{Q}_{\mathrm{F}}-(\mathrm{TVC}+\mathrm{TFC})
$$

Where, $\Pi=$ Profit of producer per unit, $\mathrm{P}_{\mathrm{F}}=$ per unit price of paddy or head rice, $\mathrm{Q}_{\mathrm{F}}=$ Quantity of paddy or head rice, $\mathrm{TVC}=$ Total variable cost of paddy or head rice, $\mathrm{TFC}=$ Total fixed cost of paddy or head rice producer. The benefit-cost ratios (BCR) ware calculated using the equations (' $\mathrm{A}$ ' for cash cost basis and ' $\mathrm{B}$ ' for full cost basis) as follows:

A. $\mathrm{BCR}=\mathrm{GR} / \mathrm{TVC}$

B. $\mathrm{BCR}=\mathrm{GR} / \mathrm{TC}$

Where, $\mathrm{GR}=\mathrm{Gross}$ return, and $\mathrm{TC}=$ Total cost

I. $\quad$ Price spread = Price paid by consumers - Price received by the Producer

II. $\quad$ Producer's share $(\%)=\frac{\text { Price received by the producer }}{\text { Price paid by the consumer }} \times 100$

Value Addition by traders

$$
\begin{aligned}
& \text { Value Addition = Gross margin }- \text { Marketing cost } \\
& \text { Gross Margin = Sale price }- \text { Purchase price }
\end{aligned}
$$

\section{Results and Discussion}

\section{Production Cost of Kataribhog Rice}

Table 1 clearly shows input wise cultivation cost of Kataribhog rice in Dinajpur district of Bangladesh. Total cost of cultivating Kataribhog rice was 38045.75 Tk./acre. Among the cost items, major share has been captured by the labor ( 37.51 percent of the total cultivation cost). Overall total input cost was found 65.70 percent whereas total fixed cost was 34.30 percent of the total cost. Rental value of land was the highest among fixed costs which was 32.99 percent of the total cost of cultivation. 
Table 1: Production cost of Kataribhog rice in Dinajpur district.

\begin{tabular}{lcc}
\hline \multicolumn{1}{c}{ Input-wise cost (Tk./acre) } & Kataribhog rice variety & \% Total cost \\
\hline Seedling development cost & 546.56 & 1.44 \\
Seed & 1315.79 & 3.46 \\
Human labor cost: & 14271.26 & 37.51 \\
$\quad$ Family labor & 3400.81 & 8.94 \\
$\quad$ Hired labor (daily wage basis) & 5870.45 & 15.43 \\
$\quad$ Hired labor (contract basis) & 5000.00 & 13.14 \\
Tillage & 2600.00 & 6.83 \\
Fertilizer cost: & 3265.18 & 8.58 \\
$\quad$ Urea & 906.88 & 2.38 \\
$\quad$ TSP & 506.07 & 1.33 \\
$\quad$ MOP & 224.70 & 0.59 \\
$\quad$ DAP & 1506.07 & 3.96 \\
Gypsum & 121.46 & 0.32 \\
Irrigation & 809.72 & 2.13 \\
herbicide & 387.04 & 1.02 \\
Insecticide & 1072.87 & 2.82 \\
Power thresher & 728.74 & 1.92 \\
Variable cost & $\mathbf{6 5 . 7 0}$ \\
Lanterest on operating capital @ 10 for 5 months & 497.98 & 1.31 \\
Total cost & 12550.61 & 32.99 \\
\hline Note: & $\mathbf{3 8 0 4 5 . 7 5}$ & $\mathbf{1 0 0 . 0 0}$ \\
\hline
\end{tabular}

Note: (Here, 1 acre $=100$ decimals, 2.47 acre $=1$ hectare and 1 quintal $=100 \mathrm{~kg}$.) Figures within parentheses indicate percentages. Source: Field Survey 2017-2018

\section{Profitability}

It was evident from Table 2 that the yield of Kataribhog rice was $1250 \mathrm{~kg} /$ acre and gross return was 51,200 Tk./acre where return of paddy and byproducts (straw) were Tk. 48750 and Tk. 2450 respectively. On full cost and current cost basis Benefit Cost Ratio (BCR) was found 1.35 and 2.05, respectively. That means, current return on investment in the Kataribhog rice production is 205 percent. Unit cost of production and return from grain of Kataribhog rice were 30.50 and $39.00 \mathrm{Tk}$. $/ \mathrm{kg}$, respectively in the study area. That means, farmers are getting benefit of $8.50 \mathrm{Tk}$. $/ \mathrm{kg}$ by producing Kataribhog rice.

Table 2: Per acre profitability of Kataribhog rice in Dinajpur District

\begin{tabular}{lc}
\hline Items & Kataribhog rice \\
\hline Total cost (Tk./acre): & $\mathbf{3 8 0 4 5 . 7 5}$ \\
$\quad$ Total variable cost & 24997.17 \\
Total imputed cost & 13048.58 \\
Yield (kg/acre) & $\mathbf{1 2 5 0 . 0 0}$ \\
Gross Return (Tk./acre): & 51200.00 \\
Return from paddy & 48750.00 \\
$\quad$ Return from straw & 2450.00 \\
Gross Margin (Tk./acre) & 13154.25 \\
Net return (Tk./acre) & 105.67 \\
Unit price of grain (Tk./kg) & 39.00 \\
Unit cost of production (Tk./kg) & 30.44 \\
BCR on cash cost basis (Undiscounted) & 2.05 \\
BCR on full cost basis (Undiscounted) & 1.35 \\
\hline
\end{tabular}

Note: (Here, 1 acre $=100$ decimals, 2.47 acre $=1$ hectare and 1 quintal $=100 \mathrm{~kg}$.) Figures within parentheses indicate percentages. Source: Field Survey 2017-2018

\section{Supply Chain of Kataribhog Rice}

The Bangladesh rice marketing channel has two segments. First segment includes supplying paddy from the farm level to the millers/processors and the second segment includes supplying rice from the millers/processors to the ultimate consumers. The first segment in supplying Kataribhog paddy included Farias, Beparies, Aratdar and rice millers. On the other hand, actors included in the second segment are rice miller, Aratdar, Bepari or wholesaler and retailer. Moreover, the Bangladeshi fine rice is being exported in US, UK and Middle-east Asian countries. Various types of marketing channels are shown in Figure 1.

On the basis of the importance given by the respondents during their selling of paddy/rice in the study areas, 
the following supply chains were identified in case of Kataribhog rice marketing.
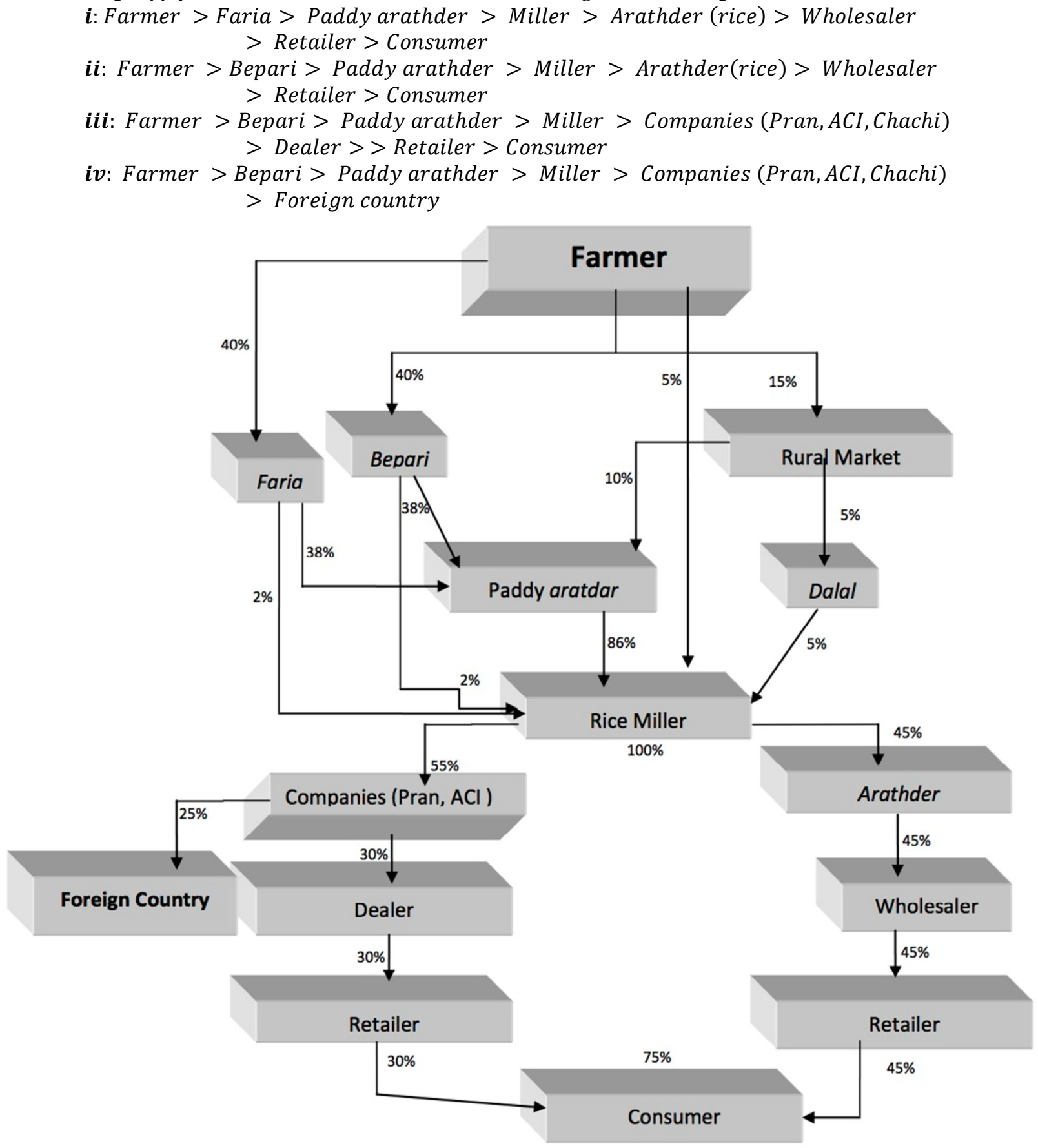

Figure 1: Supply chain of Kataribhog rice in Dinajpur, Bangladesh Source: Field survey, 2017-18

\section{Aromatic Rice Supply System in Domestic Market}

In the domestic market, about $45 \%$ aromatic rice was distributed from millers through rice aratdar, wholesaler and retailer to the consumer. On the other hand, about 55 percent of aromatic rice has been distributed by different companies of Bangladesh like Pran, ACI, Pusti and Chashi etc. The companies collected rice from the millers and then processed, packaged, leveled and sold by their own brand name. The companies marketed about $30 \%$ aromatic rice domestically and remaining $25 \%$ was exported in the foreign countries.

Ratio of Clean Rice and By-product from Kataribhog Rice

The rice mills produce four kinds of by-products besides the head rice or clean rice. These are rice husk, rice 
bran, dead rice and broken rice. The ratios of head rice, rice husk, rice bran and broken rice differ according to the types of mill. On average, the surveyed automatic mills in Dinajpur district could generate 56, 20, 8, 12 and 4 percent of head rice, rice husk, rice bran, broken rice and dead rice, respectively (Table 3). All the by-products that a mill produces have several useful applications. For example, bran and broken rice are useful for producing feed for poultry, livestock and fish sectors, while rice husks have been utilized as fuel for millers and the rural community. Now a days, rice bran is being used to produce Rice Bran Oil (RBO) commercially.

Table 3: Milling Outturn and By-products from $1000 \mathrm{~kg}$ of Paddy in Dinajpur District

\begin{tabular}{lcc}
\hline Particulars & Amount & \% of total \\
\hline Milling Outturn $(\mathrm{Kg})$ & 560 & 56 \\
Husk $(\mathrm{Kg})$ & 200 & 20 \\
Rice Bran $(\mathrm{Kg})$ & 80 & 8 \\
Broken Rice $(\mathrm{Kg})$ & 120 & 12 \\
Dead Rice $(\mathrm{Kg})$ & 40 & 4 \\
\hline
\end{tabular}

Source: Field Survey 2017-2018

\section{Marketing Cost of Bepari and Aratdar}

Per quintal marketing costs of Bepari and Aratdar has been presented in Table 3. The marketing cost has been represented as a sum total of buying and selling costs. Total marketing cost of Bepari was Tk. 81.90 per quintal among them $67.40 \%$ was buying cost. Among the marketing costs items, the highest cost $(36.64 \%)$ was for transportation followed by cost of bagging (29.30\%). Besides these, the marketing cost included cost of loading and unloading, cost for market tolls, cost for sweeper, weighing charges, electricity and personal expenses etc. Total cost of aratdar was Tk. 91.80 per quintal on which $66.34 \%$ was buying cost. Like Bepari the loin share of the marketing costs of aratdar were captured by transportation (42.48\%) and bagging (26.14\%).

Table 3: Marketing cost of Bepari and Aratdar

\begin{tabular}{|c|c|c|c|c|c|}
\hline \multicolumn{2}{|l|}{ Actors } & \multicolumn{2}{|c|}{ Baperi } & \multicolumn{2}{|c|}{ Aratdar } \\
\hline \multicolumn{2}{|c|}{ Cost Items } & $\begin{array}{l}\text { Cost (Tk/ } \\
\text { quintal) }\end{array}$ & $\begin{array}{c}\% \text { of Total } \\
\text { Cost }\end{array}$ & $\begin{array}{l}\text { Cost (Tk/ } \\
\text { quintal) }\end{array}$ & $\begin{array}{c}\% \text { of Total } \\
\text { Cost }\end{array}$ \\
\hline \multirow{7}{*}{$\begin{array}{l}\text { Buying } \\
\text { Cost }\end{array}$} & Transport cost & 15.00 & 18.32 & 24.00 & 26.14 \\
\hline & $\begin{array}{l}\text { Loading and } \\
\text { unloading }\end{array}$ & 6.00 & 7.33 & 6.00 & 6.54 \\
\hline & Market toll & 3.00 & 3.66 & 4.50 & 4.90 \\
\hline & Sweepers & 6.00 & 7.33 & 1.20 & 1.31 \\
\hline & Cost of bagging & 24.00 & 29.30 & 24.00 & 26.14 \\
\hline & Personal expenses & 1.20 & 1.47 & 1.20 & 1.31 \\
\hline & Sub-total & 55.20 & 67.40 & 60.90 & 66.34 \\
\hline \multirow{9}{*}{$\begin{array}{l}\text { Selling } \\
\text { Cost }\end{array}$} & Transportation & 15.00 & 18.32 & 15.00 & 16.34 \\
\hline & $\begin{array}{l}\text { Loading and } \\
\text { unloading }\end{array}$ & 6.00 & 7.33 & 6.00 & 6.54 \\
\hline & Personal expenses & 1.20 & 1.47 & 1.20 & 1.31 \\
\hline & Weighing charges & 3.00 & 3.66 & 0.00 & 0.00 \\
\hline & Electricity & 0.00 & 0.00 & 0.60 & 0.65 \\
\hline & Market toll & 0.00 & 0.00 & 4.50 & 4.90 \\
\hline & Others & 1.50 & 1.83 & 3.60 & 3.92 \\
\hline & Sub-total & 26.70 & 32.60 & 30.90 & 33.66 \\
\hline & Total Cost & 81.90 & 100.00 & 91.80 & 100.00 \\
\hline
\end{tabular}

Source: Field Survey 2017-2018

Processing and marketing cost of miller

The processing and marketing cost of rice included buying cost, processing cost and selling cost. The maximum cost of miller has gone for rice processing. It was 49.96 percent of the total processing and marketing costs of miller. The main rice processing cost items were labor required for soaking, parboiling, drying and milling (22.74\%), electric bill (11.70\%), and costs of bags for packing (11.18\%). Total cost of miller was Tk. 761.71 per quintal among them $24.04 \%$ and $25.99 \%$ were buying cost and selling cost, respectively. Details of the cost of processing and marketing are provided in Table 4. 
Table 4: Processing and marketing cost of miller

\begin{tabular}{l|lcc}
\hline Cost Item & & (Tk./quintal) & \% of cost \\
\hline \multirow{5}{*}{ Buying cost } & Labor (Buying, weighing \& loading) & 39.60 & 5.20 \\
& Market toll & 7.43 & 0.97 \\
& Cost of bags & 49.50 & 6.50 \\
& Rope (Sutl) & 2.48 & 0.32 \\
& Helping man (Koyal) & 4.95 & 0.65 \\
& Commission to Aratdar & 24.75 & 3.25 \\
& Transportation & 49.50 & 6.50 \\
& Unloading & 4.95 & 0.65 \\
& Sub-total & $\mathbf{1 8 3 . 1 5}$ & $\mathbf{2 4 . 0 4}$ \\
& Labor (Boiling, drying, milling \& processing) & 22.74 \\
& Electricity cost & 173.25 & 11.70 \\
& Personal expenses & 89.10 & 0.28 \\
& Subscription for association & 2.13 & 0.14 \\
& Telephone charge & 1.04 & 0.03 \\
& Storage & 0.20 & 1.30 \\
& Bagging cost & 9.90 & 11.18 \\
& Others & 85.14 & 2.60 \\
& Sub-total & 19.80 & $\mathbf{4 9 . 9 6}$ \\
& Transportation cost for Dhaka & $\mathbf{3 8 0 . 5 6}$ & 22.74 \\
& Commission to rice Aratdar & 173.25 & 3.25 \\
& Sub-total & 24.75 & $\mathbf{2 5 . 9 9}$ \\
\hline & Total & $\mathbf{1 9 8 . 0 0}$ & $\mathbf{1 0 0 . 0 0}$ \\
\hline
\end{tabular}

Source: Field Survey, 2017-2018

\section{Marketing cost of Aratdar, wholesaler and retailer}

Table 5 represents per quintal average costs of Aratdar, wholesaler and retailer. Aratdar bore less cost because they are commission agents. They are not responsible for transportation and labor costs in in the marketing system. As commission agents, the main costs of traders are salary of permanent staffs $(43.61 \%)$ and rent of the premise $(18.69 \%)$. The total marketing cost of a quintal of rice calculated for aratdars was Tk. 73.49. The total marketing cost of wholesaler was Tk. 95.57 per quintal. Among the marketing cost items, transportation cost was the highest $(34.13 \%)$ followed by the cost of bagging (29.86\%). Retailers have to incur costs like labor cost, loading and unloading charge, transportation cost etc. It was observed that the total cost of marketing incurred by retailers in the terminal market was Tk. 75.57/quintal among which transportation cost was the highest $(38.57 \%$ of the total marketing cost) followed by loading and unloading $(16.53 \%)$ and cost of bagging $(16.53 \%)$.

Table 5: Marketing cost of aratdar (rice), wholesaler and retailer (Tk. /quintal)

\begin{tabular}{lcccccc}
\hline \multirow{2}{*}{ Actors } & \multicolumn{2}{c}{ Aratdar } & \multicolumn{2}{c}{ Wholesaler } & \multicolumn{2}{c}{ Retailer } \\
\cline { 2 - 7 } & Cost Items & $\begin{array}{c}\text { \% of Total } \\
\text { Cost }\end{array}$ & Cost & $\begin{array}{c}\text { \% of Total } \\
\text { Cost }\end{array}$ & Cost & $\begin{array}{c}\text { \% of Total } \\
\text { Cost }\end{array}$ \\
\hline Unloading & 11.25 & 15.58 & 13.20 & 12.80 & 12.90 & 16.53 \\
Rent & 13.50 & 18.69 & 2.20 & 2.13 & 0.86 & 1.10 \\
Electricity charge & 2.25 & 3.12 & 1.76 & 1.71 & 2.88 & 3.69 \\
Labor charge-permanent & 31.50 & 43.61 & 8.80 & 8.53 & 8.60 & 11.02 \\
Transportation cost & 0.00 & - & 35.20 & 34.13 & 30.10 & 38.57 \\
Cost of bagging & 31.50 & 29.86 & 30.80 & 29.86 & 12.90 & 16.53 \\
Telephone charge & 0.18 & 0.17 & 0.18 & 0.17 & 0.13 & 0.17 \\
Market toll & 0.36 & 0.49 & 6.60 & 6.40 & 6.45 & 8.26 \\
Market search cost & 0.23 & 0.31 & 0.00 & 0.00 & 0.00 & 0.00 \\
Cost of lost in transportation $\&$ & 0.68 & 0.92 & 0.00 & 0.00 & 0.43 & 0.98 \\
handling & 0.68 & 0.92 & 0.00 & 0.00 & 0.86 & 0.82 \\
Personal Expenses & 4.50 & 6.23 & 4.40 & 4.27 & 3.23 & 4.13 \\
Others & 73.49 & 100.00 & 95.57 & 100.00 & 75.57 & 100.00 \\
Total & & & & & & \\
\hline Source: Finyyyyyyyyyyy
\end{tabular}

Source: Field Survey 2017-2018

Marketing margin of different actors of Kataribhog rice

Table 6 reveals that the miller shared highest cost $(64.55 \%)$ and captured highest percentage of total net profit 
(42.75\%) amongst the traders. The second highest cost was incurred by wholesaler (8.10\%) and earned 11.33 percent of the total net marketing margin. The rice retailer captured 17.92 percent of total net marketing margin by incurring 6.40 percent of the total marketing cost. The aratdar earned 11.02 percent of the net marketing margin by incurring only 6.23 percent of the total marketing cost. Share of net profit earned by the paddy aratdar and bepari were 9.42 and 7.56 percent, respectively.

Table 6: Marketing margin of different actors of Kataribhog rice (Tk. /quintal)

\begin{tabular}{lccccccccc}
\hline \multirow{2}{*}{ Actors } & \multirow{2}{*}{ Purchase Price } & \multirow{2}{*}{ Sale Price } & \multicolumn{2}{c}{ Gross Margin } & \multicolumn{2}{c}{ Cost of marketing } & \multicolumn{2}{c}{ Profit or net margin } \\
\cline { 4 - 9 } & & & Value & $\%$ & Value & $\%$ & Value & $\%$ \\
\hline Faria/Baperi & 4550 & 4737.5 & 187.50 & 7.19 & 81.90 & 6.94 & 105.60 & 7.56 \\
Aratdar (paddy) & 4737.5 & 4957.5 & 220.00 & 8.44 & 91.80 & 7.78 & 128.20 & 9.42 \\
Miller & 4957.5 & 6412.5 & 1455.00 & 55.80 & 761.71 & 64.55 & 693.29 & 42.75 \\
Aratdar (rice) & 6412.5 & 6625 & 212.50 & 8.15 & 73.49 & 6.23 & 139.01 & 11.02 \\
Wholesaler & 6625 & 6870 & 245.00 & 9.40 & 95.57 & 8.10 & 149.43 & 11.33 \\
Retailer & 6875 & 7162.5 & 287.50 & 11.03 & 75.57 & 6.40 & 211.93 & 17.92 \\
\hline
\end{tabular}

Source: Field Survey, 2017-2018

Producer share and farm retail price spread of Kataribhog rice

Producer sharer in consumer's taka is the price received by the producer expressed as percentage of the retail price (price paid by the consumer). For Kataribhog rice producer share and farm retail price spread were 63.53 percent and $2612 \mathrm{Tk}$. /quintal, respectively (Table 7). High producers share is an evidence of increasing the efficiency of the marketing system in favor of the farmer, while low producer share is an evidence of the fact that middlemen retained a large share.

Table 7: Producer share and farm retail price spread of Kataribhog rice

\begin{tabular}{lc}
\hline Item & Tk. /quintal \\
\hline Producer price & 4550 \\
Retail Price & 7162 \\
Producer Share (\%) & 63.53 \\
Farm Retail Price Spread & 2612 \\
\hline
\end{tabular}

Source: Field Survey 2017-2018

\section{Producers' constraints}

The constraints narrated by the respondents regarding production of aromatic rice is presented in Table 8. Major constraints pertaining to cultivation of aromatic rice were heavy infestation of neck blast and sheath rot diseases. Ninety five percent of the respondent farmers were reported these as the most vulnerable constraints. The other most exposed constraints were labor crisis on transplanting and harvesting period ( 85 percent), high price of pesticide and insecticide ( 80.66 per cent) etc. Lack of storage, rational price and capital formation were the considerable constraints of Kataribhog rice production in the study area.

Table7: Marketing and institutional problems of farmers in the study areas

\begin{tabular}{llc}
\hline No. & Description of the Problems & Percentage (\%) \\
\hline$\underline{A}$ & Production and Marketing aspect & 95.0 \\
\hline & Neck blast and sheath rot diseases & 85.0 \\
3 & Labor crisis on transplanting and harvesting period & 83.0 \\
4 & Lodging problems & 80.8 \\
5 & High price of pesticide and insecticide & 75.0 \\
6 & Problem of price setting & 62.5 \\
7 & Problem of storage facilities & 52.0 \\
$\mathbf{B}$ & Lack of market & 33.3 \\
\hline 1 & Financial and Institutional aspect & 45.8 \\
2 & Loan repayment problem & 41.6 \\
3 & Lack of capital availability & 20.8 \\
4 & Problems of credit facility & 37.5 \\
5 & Transport problem & 16.7 \\
6 & Lack of institutional support & 8.3 \\
7 & Problem of theft & \\
\hline
\end{tabular}

Source: Field Survey, 2017-2018 


\section{Miller's constraints}

The major problems of the rice millers in the study area were interruption in electricity supply (96\%), high transportation costs (94\%), high marketing costs (transportation costs plus others costs) 72.7 percent, capital shortage and access of credit in due time (64.4\%), price instability $(65.40 \%)$, storage unavailability $(48.20 \%)$ etc. (Table 9).

Table 9: Problems faced by rice millers

\begin{tabular}{lc}
\hline Types of Problems & $\begin{array}{c}\text { Respond by (\%) } \\
\text { Rice millers }(\mathrm{N}=25)\end{array}$ \\
\hline Uncertainty in electricity supply & 96.00 \\
High transportation cost & 94.00 \\
High marketing costs & 72.70 \\
Capital shortage and credit access in due time & 64.40 \\
Storage problem & 48.20 \\
Price instability & 65.40 \\
Milling problems & 46.40 \\
Illegal charges & 56.40 \\
\hline
\end{tabular}

Note: $\mathrm{N}=$ Total sample size by each category for Dinajpur. Source: Field Survey 2017-2018

\section{Conclusion}

Bangladesh produces several varieties of aromatic rice that has high demand in the country and abroad as well. The study found that total cost of cultivating Kataribhog rice was 38045.75 Tk./acre .On full cost and current cost basis Benefit Cost Ratio (BCR) was found 1.35 and 2.05, respectively. Millers and different companies supplied about $75 \%$ of the aromatic rice in the domestic market and remaining $25 \%$ were exported in the foreign countries. On an average costs of aromatic rice marketing for Bepari, aratdar (paddy), miller, aratdar (rice), wholesaler and retailers were estimated as Tk. 81.90, Tk. 91.80, Tk.761.71, Tk. 73.49, Tk. 95.57, and Tk. 75.57, per quintal respectively. Share of net profit earned by the faria/bepari, paddy aratdar, miller, aratdar (rice), wholesaler and retailer were estimated as $7.56 \%, 9.42 \%, 42.75 \%, 11.02 \%, 11.33 \%$ and $17.92 \%$, respectively. Producer share and farm retail price spread were 63.53 percent and $2612 \mathrm{Tk}$. /quintal respectively. The present study identified some problems and constraints associated with aromatic rice marketing. The unavailability of labor, pest and disease problem, high costs of inputs, high cost of labor, lodging problems were the major constraints of producing aromatic rice in Bangladesh. Where as lack of storage facilities, lack of information, lack of regulated and co-operative market etc. were the constraints of aromatic rice marketing. Proper planning and measures from the government side to solve the problems in the production and marketing would encourage farmers for better production of aromatic rice in the country.

\section{Suggestions}

Aromatic rice production is highly labor intensive. Some specific policies have to be developed by the government for its availability during the peak period of crop production. Disease (Blast \& Sheath rot) and pest (BPH) resistant aromatic rice varieties should be introduced. Marketing infrastructure and storage facilities should be improved. Farmers and traders should provide easy loan for aromatic rice production, processing and marketing. Market regulatory authorities should address the issues of unfair deduction at the market places.

\section{Conflicts of Interest}

The author declares no conflicts of interest regarding the publication of this paper.

\section{References}

BBS 2016. Bangladesh Bureau of Statistics, Government of the People's Republic of Bangladesh, Sher-EBangla Nagar, Bangladesh.

DAE 2017. Department of Agricultural Extension, Ministry of agriculture, Government of the People's Republic of Bangladesh.

Islam, M. Z., Khalequzzaman, M., Bashar, M. K., Ivy, N. A., Mian, M. A. K., Pittendrigh, B. R., Haque, M. M. and Ali, M. P. 2018. Variability Assessment of Aromatic Rice Germplasm by Pheno-Genomic traits and Population Structure Analysis. Scientific Reports, 8:9911 DOI:10.1038/s41598-018-28001-Z

Rashid, M.M, Ghosh, A.K., Roni, M.N., Islam, M.R. and Alam, M.M. 2017. Yield Performance of Seven Aromatic Rice Varieties of Bangladesh. International Journal of Agriculture and Environmental Research, 3(2): 2637-2642. 